\title{
3rd ICTs and Society Meeting; Paper Session - Inequalities: social, economic and political; Paper 2: Media conver- gence and blogging in exposing corruption and fraud in India
}

\author{
C.S.H.N. Murthy
}

Department of Communication and Journalism, School of Humanities and Social Sciences, Tezpur University, Napam, Tezpur Assam India 784 028; E-mail: cshnmurthy@yahoo.co.in

\begin{abstract}
The divide between the poor and the rich in India is getting wider and deeper day by day in the post globalization and privatization. It also sounds paradoxical to hear that the development whatever is happening in India is preceded by large scale corruption where the politicians and the bureaucrats in tandem and in perfect collusion are siphoning off billions of rupees meant for the rural development. But, none of these projects could escape the brunt of corruption in India. The paper deals with a few such stories of corruption as case studies that came to limelight and are placed in 'convergent' media either in the blogs of television channels or print media or on line web-portals such as face-book/twitter or on You Tube. The paper hypothesizes that the current level of exposure of corruption in $24 \times 7$ 'convergent' media is not adequate and would like to explore the ways and means of utilizing it (convergent media) more 'socially effectively' to totally curb/eliminate the corruption from the top to the lower level in the governance in India. This study therefore follows multiple methods of inquiry, besides the case studies, including surfing the existing web-portals/blogs for the mobilized public views on exposure of corruption through the 'convergent' media and conducting interviews with the convenience sample of media experts in the field as also analyzing the secondary documents (for case studies). The study is therefore a descriptive and qualitative communication research.
\end{abstract}

Keywords: Corruption, Convergent Media, blogs, television channels, web-portals, face-book, twitter

The divide between the poor and the rich in India is getting wider and deeper day by day in the post globalization and privatization (since 1990s). It also sounds paradoxical to hear that the development whatever is happening in India is preceded by large scale corruption where the politicians and the bureaucrats in tandem and in perfect collusion are siphoning off billions of rupees meant for the rural development which is a broad term and includes -rural projects taken up under the Prime Minister Gram Sadak Yojana (Prime Minister's Road Laying Scheme for Villages in India) and Mahatma Gandhi National Rural Employment Guarantee Scheme. But, none of these projects could escape the brunt of corruption in India.

The first ever 'convergent' media use for the expose of corruption in India came from Thelka.com a web portal, which used the 'sting operation' to expose the corrupt officials and their nexus with the politicians. Terming it as an 'Operation West End', the Editor-inChief wrote:

Operation West End is the ultimate indictment of Indian governance and ethics. It is the ugly fable of a poor country that has been completely sold off by its rich and powerful. We spent eleven lakhs on the story. If we had a little more money we could have ripped open the entire system end to end. We were just a group of amateurs, a leanly funded media organization with limited resources. (Tejpal, 2001)

Earlier, Tehelka.com has also brought out a story entitled Fallen Heroes which brought out the ugly side of the much hyped Indian cricket in which the cricket players happily engaged themselves for 'match fixing' for sleaze and money. This was of course the beginning of 
use of 'convergent' media by the online web portals for exposing the corruption. Ever since there were thousands of stories of corruption involving the highest officials and the politicians but none took a serious view of the escalating corruption and bureaucrat-politicians nexus though country's economy is seriously affected and the poor farmers/weavers have been committing suicides.

Strangely the revelations of IPL corruption were carried out by both Mr.Shashi Tharoor and Mr.Lalit Modi through twitter and e-mail only. Today You Tube contains the interviews given by both Mr. Shashi Tharoor and Mr.Lalit Modi on their respective stands/contentions with regard to the involvement of many more Indian politicians and officials of Board of Cricket Control of India (BCCl). But, at the same time, both Mr.Shashi Tharoor and Mr.Lalit Modi exposed their own darkside of the faces by virtue of their exposing their clandestine relationships with their girl friends too.

The paper deals with a few such stories of corruption as case studies that came to limelight and are placed in 'convergent' media either in the blogs of television channels or print media channels or on line web-portals such as face-book/twitter or on You Tube.

The purpose of choosing most of the case studies from the 'convergent' media is to show that internet both as a 'convergent' media in the form of 'face-book' and 'twitter', and as a source of quick transmission through 'e-mail' or 'chatting' is an efficient medium to report the corruption.

\section{Case Studies of Corruption}

\subsection{Prime Minister Gram Sadak Yojana}

Strangely the Prime Minister of India Mr. Manmohan Singh himself has admitted to the large scale corruption taking place in the projects run in the Prime Minister's name in India. Delivering a memorial lecture in recognition of the fight waged by an IIT graduated engineer Mr. Satyendra Nath Duby who was murdered for exposing the corruption in laying the Golden Quadrangle Road, Manmohan Singh made candid admission that "A major reason for poor quality roads is corruption that has been spreading like cancer across the country." (Kumar \& Sen ,2007)

\subsection{Mahatma Gandhi National Employ- ment Guarantee Scheme}

Under National Employment Guarantee Scheme, which came into existence under NREG Act (Feb 2, 2006), the Government of India intended to generate an assured employment for a minimum of 100 days in all districts and rural areas of India so that migration of labour to the urban centres can be stopped in the first instance. Further, it would provide payment of remuneration at the rates prescribed by the government and the local government officials would have to disburse the payments. All the eligible unemployed would be provided identity cards which would enable them to get employed by the local governments to construct short term projects, roads, tanks, school and hospital buildings, etc. Unfortunately, the government officials at the local government level began to produce false records and swindled the amount meant for the generation of employment. (see Bhattacharya, 2008)

A journalist, namely K. Sudhakar Patnaik, who covered the areas Koraput, Bolangir and Kalahandi, where the scheme has been put up, has written in an online webportal as follows:

As a journalist, with an experience of over 25 years, I found the NREGA, the biggest and noblest anti-poverty scheme in the post-independence India. However, the biggest noble scheme seems defeated in KBK districts. The officers looted, and are still looting, the poor men's money in an organised way by taking advantage of their innocence and illiteracy. A visit to some villages under the Kaberibadi and the Pedalada panchayats under the Bandhugaon block in Koraput district reveals the pathetic condition of the Kondh tribe. The government, the local elected representatives and the government officials ignore all the 23 villages, which are on the other side of the river Jhanjabati. The tribals living there do not know any other languag, apart from their own dialect Koya, Telugu and a bit of Oriya language. (Patnaik, 2008)

\subsection{Scandal in the Public distribution (PDS)}

The public distribution system in India, established in 1997 by the government of India 
to provide food security to the need and poor, one of the largest public relief systems in the world, has been worst hit when it came to lime light that there was a scandal of diverting the public food meant for the distribution for the people below the poverty life (BPL) which amounted to 3000 billions of rupees of fraud.

Commenting on how corruption has led to the miserable failure of the best intentions of the government to provide food security to the people who are affected by the unemployment, poverty and malnourishment, the Asian Legal Resource Centre Internet site has posted on May 312007 the following note.

India is a country of contradictions. A country that has a projected $9 \%$ development index performs worse than some Sub-Saharan countries with regard to addressing starvation and malnourishment within its territory. The National Minimum Programme promulgated by the Government of India in 2004 speaks about the Rural Employment Guarantee programme, which is also reflected in India's voluntary pledge to the United Nations Human Rights Council. However, millions of Indians in rural villages are not benefiting from this programme and remain unemployed. The programme is not properly implemented and in places where there are possibilities of implementation and thus employment, recruitment to the programme is based on caste bias and nepotism. Poverty and resultant starvation in India is not limited to the lower caste, although they suffer the most. The lower caste forms only about $20 \%$ of the Indian population, whereas starvation and malnourishment affect about $53 \%$ of its entire population. .........For example, for the distribution of food to targeted population the government has established the Public Food Distribution System (PDS). However, the management of this system suffers from corruption - particularly black marketing, caste prejudices and the utter failure of various local governments. (Asian Legal Resource Centre, 2007).

\subsection{Scandals in Irrigation Projects in State of Andhra Pradesh}

While these schemes formulated by the Centre ended up in large scale dwindling of funds by the grass root officials in nexus with the local politicians, the other side of the corruption occurs in the state level irrigation projects launched by the regional governments such as what one finds in the State of Andhra Pradesh where allegations are rife now that billions of rupees were given as kickbacks to the Ministers and the Members of Legislative bodies by the contractors who were favoured with the large scale tenders for the construction of these projects. An online web-portal www.zimbo.com has reported the findings of the Public Affairs Committee, headed by Dr. Nagam Janardhana Reddy and other members of the Legislative Assembly, which stated that about 11 billion rupees have been paid just for a design of a project which has not yet been launched so far (see Rashmi, 2010). The finding was shocking not only to the Legislators of both the ruling and the opposition party but also to the people of the State per se.

While exploring the causes of Satyam (an internationally reputed software solutions exporting company) fraud, Raghuvir Srinivasan wrote in the web portal www.ghotala.in that

there is the political angle to the scandal. Mr Raju and his companies (Maytas group) have been beneficiaries of large public contracts for transport systems and irrigation projects in Andhra Pradesh. Nexus between businessmen and politicians is an accepted reality in this country. So is someone powerful attempting now to protect Mr Raju? Or is it that he knows too much about wheeling-dealings and hence needs to be kept away from investigators? (Srinivasan, 2009)

The regional print and electronic media are agog with the discussions of these corruption stories day by day. People, within the ruling Congress party, which is running the State Government in Andhra Pradesh, are levelling serious charges of corruption against their own Irrigation Minister Mr. Ponnala Lakshmaiah, a foreign returned backward class Engineer.

\subsection{Scandals in IPL lead to dismissal of Lalit Modi and dropping the Minister Mr. Shashi Tharoor}

Recently, Shashi Tharoor, the ex-minister for State for external affairs in the Prime Minister's cabinet exposed how large scale corruption was involved in the Indian Premier League (IPL) Cricket Matches. In reaction to this revelation, Lalit Modi, the IPL Chairman implicated Shashi Tharoor stating that Minister's girl friend possessed shares in the IPL Kochi to the extent of billions of rupees. In the 
process of revelations, most of which were carried using internet and e-mail, besides convergent web site You Tube, both the State level Minister Mr. Shashi Tharoor and the Chairman IPL Mr. Lalit Modi lost their offices of power.

But, globally both the highly educated people brought disrepute to India. A further set back was that the rosy picture that was painted for the credibility of these IPL tournaments and Indian cricket as a whole for that matter has suddenly vanished in to thin air with the allegations and counter allegations of match fixing. It did not stop there. It has further exposed the corruption and the nexus between the politicians and the business magnates of Bombay. Evidence started trickling as to how the daughters of the Cabinet Ministers Mr.Sharad Pawar and Mr. Prafulla Patel had clandestinely involved themselves in the IPL auctions through the backdoor agencies/agents.

The Times Live in its web portal wrote that:

The Mumbai Indians and Chennai Super Kings face each other in the Indian Premier League cricket final today amid a scandal that has rocked the multibillion-dollar tournament. The government launched a probe this week following startling revelations by IPL chief Lalit Modi that led to the resignation of a minister and claims by the opposition that the league was a front for money laundering and illegal betting. India's junior foreign minister, Shashi Thahoor, quit after Modi revealed on Twitter the ownership structure of a new IPL franchise, which showed a free stake had been given as a gift to the politician's girlfriend. (Times Live, 2010)

\subsection{President of Indian Medical Council- Ketan Desai indulges in large-scale corruption}

The most recent scandal that rocked the consciousness of the entire country was that of the president, Mr. Ketan Desai, Indian Medical Council who was caught while taking 20 million rupees as bribe by the Central Bureau of Investigation for giving licence to medical college in Punjab which does not fulfill the criteria laid down for opening a medical college in India. Immediately after this incident, the Central Government dissolved the Medical Council of India and appointed a 7 member ad-hoc committee to steer the licensing of Medical Colleges till alternative permanent set up is established. (The Tribune, no date)

\section{Conceptual frame work}

The effort of this paper is to explore the ways and means of utilizing it more 'socially effectively' to totally curb/eliminate the corruption from the top to the lower level in the governance in India. The study also believes that the existing exposure of corruption in India is not commensurate with the magnitude of corruption.

With the fast spread of 'internet' to the rural India and television channels touching a roaring number of 450 including regional channels, the study assumes that there is very good scope to combine both these media efficiently into a 'convergent' media to expose the corruption on a $24 \times 7$ basis. Given the largest membership for the 'face-book' and the 'twitter', the public reporting of corruption in all aspects of governance could be increased in geometric proportions.

This study therefore follows multiple methods of inquiry, besides the case studies, including interviews with the media experts in the field (not yet completed by the date of the conference) and analysis of secondary documents (for case studies). The study also surfs for the internet based sites/blogs where the NGOs/web-portals established some discussion the corruption through blogs.

\subsection{Methodology}

The study is therefore a descriptive and qualitative communication research.

\subsubsection{Sample}

The media experts of a convenience sample would be asked to address open ended questions, the answers of which would be analyzed and compared with the views of the people expressed through various blogs/twitters/opinions in various websites and web-portals (yet to complete). 


\subsubsection{Hypotheses}

1. This paper hypothesizes that 'corruption' leads to 'inequality' in society and 'more corruption' means 'more accentuation' of 'inequality'.

2. The study also pre-supposes that more the 'digital divide', the greater the 'inequalities' in the society.

3. The study further posits that 'social', 'economic' and 'political' inequalities in the society staggeringly increase the corruption either due to the disoriented spectrum of digital access or due to the improper or nonapplication of digital access.

4. The study also pre-supposes that aggressive exposure of corruption through $24 \times 7$ web-portals/web-sites/blogs/twitters would effectively reduce the corruption levels in the country at all levels.

\section{Discussion}

In India, in spite of increased digital access to the people through satellite based communication revolution such as mobile phoning, telecom density, rapid penetration of internet to the rural level, the 'inequalities' engendered due to the high volume of 'corruption' continue to dog the society.

At the same time, there are no blogs/ websites, as much as required for a highly populous country like India, to expose the corruption in the government. To some extent some sting operations by certain scrupulous television channels exposed the corruption at the highest level of government. But, this is not sufficient enough to show the entire havoc of corruption. Some web-portals like http://toostep.com are carrying out a public mobilizing exercise to fight against the corruption.
Recently this website has taken a statement of the Prime Minister to the administrators -Use New Technologies to fight Corruption: PM tells Civil Servants-and called for a public opinion. It has elicited some responses from the viewers:

It is a very good idea, but our political system may not allow implementing the idea. It is necessary to make responsible and accountable for all working as public servants, all projects and programmes implemented by government should be verified after completion and its impact even after every year to know the quality of execution, all activities of a public servant in office should be open to public for scrutiny if necessary, e-goverance should be implemented in all office and businesses to check corruption. In my opinion, every paisa should spend in a business alike even for the poverty eradication or any other public issue to know the ultimate benefit either tangible or intangible. This kind of analysis will spell out the loopholes of failures in spending of public money, which can be controlled to check the corruption. (Mohanty, no date)

Both the responses have demanded more and more use of technology to week out corruption and called for a vigilant society to awake to such reports of corruption as soon as they are published in 'internet' or blogs or twitter, etc.

\section{Conclusions}

As the mainstream media is failing in exposing the enormous corruption in the government, there is a need to use the 'convergence' and 'blogging' to expose the corruption from the people side. So far no such 'convergence' or 'blogging' is exclusively designed for exposing the corruption in India. Nor are there many websites/web-portals or face-books or twitters exclusively dedicated for this job.

\section{References}

Asian Legal Resource Centre (2007, May 31). INDIA: Widespread corruption in the Public Food Distribution System causing starvation deaths. Retrieved from http://www.alrc.net/doc/mainfile.php/alrc st2007/417/

Bhattacharya, D. P. (2008, February 11). Massive corruption hits NREGA implementation. Indian Express. Retrieved from http://www.expressindia.com/latest-news/massive-corruption-hits-nrega-implementation/271528/

Kumar, P. \& Sen, A. (2007, May 24). Corruption makes growth road (Web log comment). Retrieved from http://ibnlive.in.com/news/corruption-makes-growth-road-difficult/41241-3.html?from=prestory 
Mohanty, S.K. (no date). Use new technologies to fight corruption: PM to civil servants (Web log comment). Retrieved from http://toostep.com/idea/use-new-technologies-to-fight-corruption-pm-to-civil-servant

Patnaik, K. S. (2008, April 14). NREGA: Corruption mars welfare security. Merinews. Retrieved from http://www.merinews.com/article/nrega-corruption-mars-welfare-security/132461.shtml

Rashmi, P. (2010, June 22). Rs 1,100 cr just to design a project in andhra. Zimbio. Retrieved from http://www.zimbio.com/AP+Politics/articles/H05fK6UluJi/Rs+1+100+cr+just+design+project+andhra

Srinivasan, R. (2009, January 11). Satyam fraud: More than accounting skull duggery (Web log comment). Retrieved from http://www.ghotala.in/2009/01/11/satyam-fraud-more-than-accounting-skullduggery/

Tejpal, T. J. (2001). Sleaze, senseless greed and dirty heroes. Tehelka. Retrieved from http://www.tehelka.com/channels/investigation/tarun.htm

The Tribune (no date). A new medical council. No tears need be shed for the outgoing one. Retrieved from http://www.tribuneindia.com/2010/20100515/edit.htm\#1

Times Live (2010, April 25). IPL cricket rocked by kickback scandal. Retrieved from http://www.timeslive.co.za/sundaytimes/article418539.ece/IPL-cricket-rocked-by-kickback-scandal

\section{About the Author}

C.S.H.N.Murthy

Associate Professor, teaches Film and TV Production for the Graduate and Post Graduate Students in Mass Communication. He earlier worked as an Assistant Professor in the Department of Adult and Media Education, Ministry of Education, Government of Eritrea, Asmara, Eritrea for two years during 2003-2005, Assistant Professor (Reader) in Communication at Amity University, Noida, UP and Professor in Mass Communication and Journalism at IMS, Noida. UP. India His articles were published in international journals such as Journal of Adult and Continuing Education (UK-NIACE), Educational Media International, (Taylor and Francis), Turkish Online Journal of Distance Education (TOJDE-Turkey) and The Hoot, (www.thehoot.org). He presented a number of papers at numerous international conferences (peer reviewed) organized by the AACE (USA), and at the Pan Commonwealth Forum 5 (PCF5) Conference jointly organized by Commonwealth of Learning (COL) and University of London, London, UK (July13-17, 2008), and at the End of Journalism, Technology, Education, Ethics conference? -- held at University of Bedfordshire, Luton, UK between Oct 17-18, 2008. He also presented papers at AMIC Conference held in July 13-16, 2009 at New Delhi and at IAMCR Conference held at Mexico in July 24-27, 2009. His papers were also presented recently at the Change of Progress Conference organized by University of Bucharest, Romania Nov 20-21, 2009) and at Community Broadcasters Association of Australia, (CBAA), Brisbane (Nov 17-19, 2009) Australia. 